\title{
PENGARUH INTEGRITAS DAN SKEPTISISME PROFESIONAL AUDITOR TERHADAP KUALITAS AUDIT (Studi Kasus Pada Kantor Akuntan Publik Jakarta Selatan)
}

\author{
Nihestita ${ }^{1}$, Iin Rosini ${ }^{2}$, Dani Rahman Hakim ${ }^{3}$, Desi Kurniawati ${ }^{4}$ \\ ${ }^{1}$ Akuntansi S1, Universitas Pamulang, Tangerang-Banten \\ ${ }^{234}$ Akuntansi D3, Universitas Pamulang, Tangerang-Banten \\ ${ }^{2}$ Hafizh_iin@Yahoo.com
}

ABSTRAK

Penelitian ini bertujuan untuk menganalisis secara empiris pengaruh integritas dan skeptisisme professional Auditor terhadap kualitas audit. Penelitian ini dilakukan di Jakarta Selatan dengan responden auditor yang bekerja pada Kantor Akuntan Publik di Jakarta Selatan. Penelitian ini merupakan penelitian deskriptif kuantitati. Data yang digunakan berupan data primer, dengan pengumpulan sampel menggunakan purposive sampling. Pengolahan data menggunakan regresi berganda. Auditor harus mampu mendeteksi kecurangan laporan keuangan yang mungkin saja dilakukan oleh manajemen, maka yang menjadi inti permasalahannya adalah integritas dan skeptisisme profesionalisme auditor dalam mendeteksi adanya kecurangan masih dipertanyakan.Tujuan penelitian untuk menguji dan menganalisis pengaruh integritas terhadap kualitas audit, skeptisisme profesional auditor berpengaruh terhadap kualitas audit. Hasill penelitian menunjukan bahwa integritas berpengaruh terhadap kualitas audit. Skeptisisme profesional auditor berpengaruh terhadap kualiats auditor. Penelitian ini memberikan pemahaman mengenai integritas seorang auditor dan skeptisisme profesional auditor dengan kualitas auidtor, selama ini penelitian mengenai varaibel tersebut jarang diteliti, dengan adanya penelitian ini maka akan memberikan masukan kepada auditor bahwa seorang auditor harus memiliki sikap integritas seorang auditor dan skeptisisme profesional auditor agar laporan yang dihasilkan berkualitas.

Kata kunci :Integritas, Skeptisisme Profesional Auditor, Kualitas Audit.

\section{INFLUENCE OF INTEGRITY AND PROFESSIONAL AUDITOR SKEPTICISM TO AUDIT QUALITY (Case Study at Public Accountant Office of South Jakarta)}

\section{ABSTRACT}

This study aims to analyze empirically the influence of integrity and professional skepticism of Auditors on audit quality. This research was conducted in South Jakarta with auditor respondents working at Public Accounting Firm in South Jakarta. This research is descriptive quantitative research. The data used are primary data, with sample collection using purposive sampling. Data processing using multiple regression. Auditor should be able to detect fraudulent financial statements that may be done by the management, then the core problem is the integrity and skepticism of auditor professionalism in detecting the fraud is still questioned. The purpose of research to test and analyze the influence of integrity on audit quality, professional skepticism auditor influence audit quality. Hasill research shows that integrity affects audit quality. Professional auditors' skepticism influences the auditor's quality. This study provides an understanding of the integrity of auditors and professional skepticism of auditors with 


\section{National Conference of Creative Industry: \\ Sustainable Tourism Industry for Economic Development}

Universitas Bunda Mulia, Jakarta, 5-6 September 2018

ISSN No: 2622-7436

quality of auidors, so far the research on varaibel is rarely studied, with this research will provide input to the auditor that an auditor must have an auditor's attitude of auditor integrity and professional skepticism to report the resulting quality.

Keywords: Integrity, Auditor Professional Skepticism, Quality Audit

\section{PENDAHULUAN}

\section{A. Latar Belakang Masalah}

Berdasarkan Standar Profesional Publik (SPAP) Audit yang dilaksanakan Auditor dapat berkualitas jika memenuhi standar atau ketentuan Auditing. Ketentuan dan standar ini sangat berpengaruh terhadap kualitas audit. Karena pada dasarnya Auditor merupakan profesi yang lahir dan besar dari tuntutan publikakan adanya mekanisme komunikasi independen antara entitas ekonomi dengan para stockholder terutama berkaitan dengan akuntabilitas entitas yang bersangkutan. Profesi Akuntan Publik merupakan profesi kepercayaan masyarakat karena profesi inilah masyarakat memperoleh informasi keuangan yang andal sebagai dasar pengambilan keputusan baik untuk pihak internal ataupun eksternal. Sehingga Auditor harus melaksanakan tugasnya dengan prinsip-prinsip audit, standar-standar audit yang telah ditetapkan oleh IAI (Ikatan Akuntan Indonesia) agar dapat menghasilkan suatu laporan audit yang berkualitas.

Profesi Akuntan Publik ini merupakan salah satu profesi kunci di era globalisasi untuk mewujudkan persaingan bisnis yang transparan, oleh karena itu profesionalisme akuntabilitas mutlak diperlukan, dengan mensyaratkan tiga hal utama yang harus dipunyai oleh setiap anggota profesi, yaitu keahlian, berpengetahuan, dan berkarakter. Dari hasil penelitian, analisa serta pendapatdari Akuntan Publik tehadap laporan keuangansuatu perusahaan akan sangat menentukan dasar pertimbangan dan pengambilan keputusanbagi seluruh pihak ataupun publik yang menggunakannya.

Kualitas audit yang baikakan tercapai apabila seorang Auditor dapat memenuhi syarat berdasarkan Standar Profesinal Akuntan Publik (SPAP) yaitu standar umum, standar pekerjaan lapangan dan standar laporan.Selain mematuhi Standar Profesional Akuntan Publik (SPAP),Auditor juga harus mengetahui tentang prinsip dasar akuntansi atau PSAK.Laporan audit harus menyatakan apakah laporan keuangan telah disusun sesuai prinsip akuntansi yang berlaku umum di Indonesia. Seperti yang tertera pada standar pelaporan audit, harus disertakan kesesuainnya laporan keuangan dengan prinsip akuntansi yang berlaku di Indonesia.Auditorharus memiliki sikap integritas dan skeptisisme profesionaldalam melakukan audit agar suatu laporan keuangan dapat dipercaya. Kepercayaan ini akan berkurang apabila seorang Auditor bersikap tidak integritas dan profesional dalam fakta.Karena dalam faktanya Auditing adalah membedakan antara fakta dan kriteria.Kepercayaan masyarakat inilah yang akan membuat seorang Auditor dapat memberikan kesan baik terhadaplingkungan. Sehingga dari audit inilah pihak Manajemen maupun Investor dapat mengetahui informasi yang terdapat dalam laporan audit tersebut.

Dalam kenyataannya Profesi Jasa Akuntan sering terjadi pelanggaran.Seperti Kasus yang paling fenomenal mengenai pembuat keputusan tanpa memperhatikan kode etik profesi yang pernah terjadi di dunia adalah kasus mengenai Enron.Kasus penipuan data laporan keuangan PT Enron dan KAP Arthur Andersen.Dalam kasus Enron diketahui terjadinya perilaku moral hazard di antaranya manipulasi laporan keuangan dengan mencatat keuntungan US $\$ 600$ juta padahal perusahaan mengalami 


\section{National Conference of Creative Industry: \\ Sustainable Tourism Industry for Economic Development}

Universitas Bunda Mulia, Jakarta, 5-6 September 2018

ISSN No: 2622-7436

kerugian.Enron merupakan salah satu perusahaan besar pertama yang melakukan out sourcing secara total atas fungsi internal audit perusahaan.

Kecurangan yang dilakukan oleh Arthur Andersen telah banyak melanggar prinsip etika profesi Akuntan diantaranya yaitu melanggar prinsip integritas dan perilaku profesional.KAP Arthur Andersen tidak dapat memelihara tingkat integritas dan profesionalnya sebagai Kantor Akuntan Publik yang memberikan jasa.Sesuai dengan aturan etika Kompartemen Akuntan Publik dalam komisi dan fee referal dijelaskan bahwa anggata KAP tidak diperkenakan untuk memberikan/menerima komisi apabila pemberian/penerimaan komisi tersebut dapat mengurangi integritas dan independensi.

Skandal kasus diatas memunculkan berbagai pertanyaan masyarakat apakah ketidakwajaran tersebut mampu terdeteksi oleh Akuntan Publik yang mengaudit laporan keuangan tersebut. Auditor harus mampu mendeteksi kecurangan laporan keuangan yang mungkin saja dilakukan oleh manajemen, maka yang menjadi inti permasalahannya adalah integritas danskeptisisme profesionalismeAuditor dalam mendeteksi adanya kecurangan masih dipertanyakan.Namun, jika yang terjadi justru Akuntan Publik ikut mengamankan praktik kecurangan tersebut, maka inti permasalahannya adalah Integritas Auditor.

Transparansi serta kejujuran dalam pengelolaan lembaga yang merupakan salah satu derivasi amanah reformasi ternyata belum sepenuhnya dilaksanakan oleh salah satu Badan Usaha Milik Negara (BUMN), yakni PT Kereta Api Indonesia. Dalam laporan kinerja keuangan tahunan yang diterbitkannya pada tahun 2005, dan mengumumkan bahwa keuntungan sebesar Rp. 6,90 milyar telah diraihnya. Padahal, apabila dicermati, sebenarnya harus dinyatakan menderita kerugian sebesar Rp. 63 milyar.

Kerugian ini terjadi karena PT Kereta Api Indonesia telah tiga tahun tidak dapat menagih pajak pihak ketiga. Tetapi, dalam laporan keuangan itu, pajak pihak ketiga dinyatakan sebagai pendapatan. Padahal, berdasarkan standar akuntansi keuangan, ia tidak dapat dikelompokkan dalam bentuk pendapatan atau asset. Dengan demikian, kekeliruan dalam pencatatan transaksi atau perubahan keuangan telah terjadi di sini.

Selain untuk meningkatkan kepercayaan masyarakat terhadap Integritas dan Skeptisisme ProfesionalAuditor maka pekerjaan akuntan dan operasi Kantor Akuntan Publik (KAP) perlu dimonitor dan diaudit oleh sesama Auditor guna menilai kelayakan desain sistem pengendalian kualitas audit. Sehingga dapat memberikan output yang dihasilkan dapat mencapai standar kualitas yang tinggi.

Penelitian mengenai kualitas audit itu penting bagi KAP dan Auditor agar mereka dapat mengetahui faktor-faktor yang mempengaruhi kualitas audit dan selanjutnya dapat meningkatkan kualitas audit yang dihasilkannya. Bagi pemakai jasa audit, penelitian ini penting untuk menilai sejauh mana tingkat konsistensi Auditor dalam menjaga kualitas auditnya.

Atas dasar latar belakang di atas, maka peneliti mengangkat judul "Pengaruh Integritas dan Skeptisisme Profesional Auditor terhadap Kualitas Audit”.

\section{B. Identifikasi Masalah}

1. Kurangnya pengetahuan dan pemahaman yang dimiliki oleh seorang Auditor mengenai Integritas Auditor.

2. Kurangnya penerapan sikap kepatuhan dan tanggung jawab seorang Auditor terhadap peraturan - peraturan yang berlaku.

3. Kurang konsistennya dalam praktik Skeptisisme Profesional 


\section{National Conference of Creative Industry: \\ Sustainable Tourism Industry for Economic Development}

Universitas Bunda Mulia, Jakarta, 5-6 September 2018

ISSN No: 2622-7436

\section{Tujuan Penelitian}

1. Untuk Mengetahui pengaruh integritas auditor terhadap kualitas audit yang dilakukan Jasa Akuntan Publik di daerah Jakarta Selatan.

2. Untuk Mengetahui pengaruh skeptisisme professional terhadap kualitas audit yang dilakukan Jasa Akuntan Publik di daerah Jakarta Selatan.

3. Untuk Mengetahui pengaruh integritas auditor dan skeptisisme profesional terhadap kualitas audit para Akuntan Publik di daerah Jakarta selatan.

\section{TINJAUAN PUSTAKA}

\section{A. Auditing}

Auditing adalah suatu pemeriksaan yang dilakukan secara kritis dan sistematis, oleh pihak yang independen, terhadap laporan keuangan yang telah disusun oleh manajemen, beserta catatan-catatan pembukuan dan bukti-bukti pendukungnya, dengan tujuan untuk dapat memberikan pendapat mengenai kewajaran laporan keuangan tersebut (Sukrisno Agoes :2004).

Definisi Konrath (2002) Auditing adalah proses sistematis untuk secara objektif mendapatkan dan mengevaluasi bukti mengenai asersi tentang kegiatan-kegiatan dan kejadian-kejadian ekonomi untuk menyakinkan tingkat keterkaitan antara asersi tersebut dengan kriteria yang telah ditetapkan dan mengkomunikasikan hasilnya kepada pihakpihak yang yang berkepentingan.

\section{B. Integritas}

Menurut KBBI ( Kamus Besar Bahasa Indonesia), Integritas adalah mutu, sifat, atau keadaan yang menunjukkan kesatuan yang utuh sehingga memiliki potensi dan kemampuan memancarkan kewibawaan dan kejujuran. Integritas merupakan suatu elemen karakter yang mendasari timbulnya pengakuan profesional. Integritas merupakan kualitas yang mendasari kepercayaan publik dan merupakan patokan bagi anggota dalam menguji semua keputusan yang diambilnya. Integritas mengharuskan seorang anggota untuk bersikap jujur dan berterus terang tanpa harus mengorbankan rahasia penerima jasa, Pelayanan dan kepercayaan publik tidak boleh dikalahkan oleh keuntungan pribadi. Integritas dapat menerima kesalahan yang tidak disengaja dan perbedaan pendapat yang jujur, tetapi dapat menerima kecurangan atau peniadaan prinsip. (Mulyadi, 2002)

Indikator Integritas antara lain sebagai berikut :

a. Memahami dan mengenali perilaku sesuai kode etik.

b. Melakukan tindakan yang konsisten dengan nilai (value) dan kenyakinannya.

c. Bertindak berdasarkan nilai (value) meskipun sulit untuk melakukan itu.

d. Bertindak berdasarkan nilai (value) walaupun ada resiko atau biaya yang cukup besar.

\section{Skeptisisme Profesional}

Skeptisisme adalah paham yang memandang sesuatu selalu tidak pasti, meragukan, mencurigakan (Wikipedia). Skeptisisme profesional sendiri belum memiliki definisi yang pasti (Hurtt, 2003, dan Quadackers, 2009), namun dari definisi kata skeptisisme dan profesional, dapat disimpulkan bahwa skeptisisme profesional Auditor 


\section{National Conference of Creative Industry: \\ Sustainable Tourism Industry for Economic Development}

Universitas Bunda Mulia, Jakarta, 5-6 September 2018

ISSN No: 2622-7436

adalah sikap Auditor yang selalu meragukan dan mempertanyakan segala sesuatu, dan menilai secara kritis bukti audit serta mengambil keputusan audit berlandaskan keahlian auditing yang dimilikinya. Skeptisisme bukan berarti tidak percaya, tapi mencari pembuktian sebelum dapat mempercayai suatu pernyataan (Center for Audit Quality, 2010).

Standar umum ketiga berbunyi: "Dalam pelaksanaan audit dan penyusunan laporannya, Auditor wajib menggunakan kemahiran profesionalnya dengan cermat dan seksama."

\section{Kualitas Audit}

De Angelo (1981) mendefinisikan kualitas audit sebagai probabilitas dimana seorang Auditor menemukan dan melaporkan tentang adanya suatu pelanggaran dalam sistem akuntansi kliennya. Hasil penelitiannya menunjukkan bahwa KAP yang besar akan berusaha untuk menyajikan kualitas audit yang lebih besar dibandingkan dengan KAP yang kecil. Deis dan Giroux (1992) melakukan penelitian tentang empat hal dianggap mempunyai hubungan dengan kualitas audit yaitu (1) lama waktu Auditor telah melakukan pemeriksaan terhadap suatu perusahaan (tenure), semakin lama seorang Auditor telah melakukan audit pada klien yang sama maka kualitas audit yang dihasilkan akan semakin rendah, (2) jumlah klien, semakin banyak jumlah klien maka kualitas audit akan semakin baik karena Auditor dengan jumlah klien yang banyak akan berusaha menjaga reputasinya, (3) kesehatan keuangan klien, semakin sehat kondisi keuangan klien maka akan ada kecenderungan klien tersebut untuk menekan Auditor agar tidak lama dalam menjalankan tugasnya.

\section{METODE PENELITIAN}

\section{A. Teknik Pengambilan Sampel}

Populasi penelitian ini adalah Auditor yang berada di wilayah Jakarta Selatan. Metode pengambilan sampel dalam penelitian ini menggunakan simple random sampling. Dalam hal ini, responden tidak dibatasi oleh jabatan auditor pada KAP (partner, senior, atau junior Auditor) sehingga Auditor yang bekerja di KAP dapat diikutsertakan sebagai responden. Adapun responden dalam penelitian ini adalah Auditor pada KAP di Jakarta Selatan, dari 100 kuesioner yang di bagikan terdapat 40 kuesioner yang kemabli dan memenuhi kriteria responden.

\section{B. Sumber dan Metode Pengumpulan Data}

Penelitian ini menggunakan data primer, metode pengumpulan data yang digunakan dalam penelitian ini melalui penyebaran kuesioner, penyebaran kuesioner dengan memberikan pernyataan kepada para responden untuk diisi. Kuesioner yang dibagikan menggunakan skala likert dengan nilai 1 sampai dengan 5, dengan pernyataan sangat tidak setuju sampai dengan sangat setuju. Penyebaran kuesioner dilakukan selama 3 bulan yaitu bulan November 2017 sampai Januari 2018. Proses penyebaran kuesioner dilakukan dengan cara datang langsung ke KAP di wilayah Jakarta Selatan, kemudian setiap 2 minggu penelitian kembali mendatangi KAP untuk menanyakan kuesioner yang telah disebarkan.

\section{Metode Analisis Data}

\section{Uji Kualitas Data}

Uji kualitas data yang mencakup yaitu Uji Validitas, dan Uji Reliabilitas. Uji validitas dilakukan dengan melihat nilai total item dikoreksi dari setiap item pertanyaan yang diuji melalui scale dalam SPSS versi 22. Sedangkan uji reliabilitas dilakukan dengan melihat nilai Alpha Cronbanch. 


\section{Uji Asumsi Klasik}

Pendekatan analisis yang dilakukan dalam penelitian ini adalah ordinary least square atau derajat terkecil. Salah satu syarat mutlak dilaksanakannya analisis tersebut adalah data harus terbebas dari gangguan-gangguan statistik yang dapat membuat data tidak dapat diestimasi. Sebagai upaya mengetahui apakah data-data penelitian ini dapat dianalisis dengan OLS, maka dilakukan uji asumsi klasik yang mencakup uji normalitas, heteroskedaktisitas, multikolinieritas, dan autokorelasi

\section{Analisis Data}

\section{a. Model regresi berganda}

$$
\mathrm{Y}=\mathrm{a}+b_{1} X_{1}+b_{2} X_{2}+\mathrm{e}
$$

Penjelasan model diatas adalah sebagai berikut.

$$
\begin{aligned}
& \mathrm{Y} \quad=\text { Kualitas audit } \\
& b_{1} \ldots b_{2} \quad=\text { koefisien regresi } \\
& X_{1}=\text { Integritas Auditor } \\
& X_{2}=\text { Skeptisisme Profesional Auditor } \\
& \mathrm{a}=\text { konstan } \\
& \mathrm{e}=\text { error terms }
\end{aligned}
$$

\section{b. Pengujian T-Test}

Pengujian hipotesis yang dilakukan dalam penelitian ini menggunakan uji $t$, atau uji parsial. Tujuannya adalah untuk menguji hipotesis yang bersifat parsial atau individual.

D. $\mathrm{t}$ hitung $=\frac{r_{p} \sqrt{n-3}}{\sqrt{1-r_{p}^{2}}}$

E. $r_{p}=$ korelasi parsial yang ditemukan

F. $\mathrm{n} \quad=$ jumlah sampel

G. $t$

$=\mathrm{t}$ hitung yang selanjutnya dikonsultasikan dengan $\mathrm{t}$ tabel

\section{Kerangka Pemikiran}

Penelitian ini menguji variabel integritas berpengaruh terhadap kualitas audit, variabel skeptisisme profesonal audit berpengaruh terhadap kualitas audit. Untuk menggambar pengujian penelitian maka ditunjukan dalam kerangka pemikiran sebagai berikut:

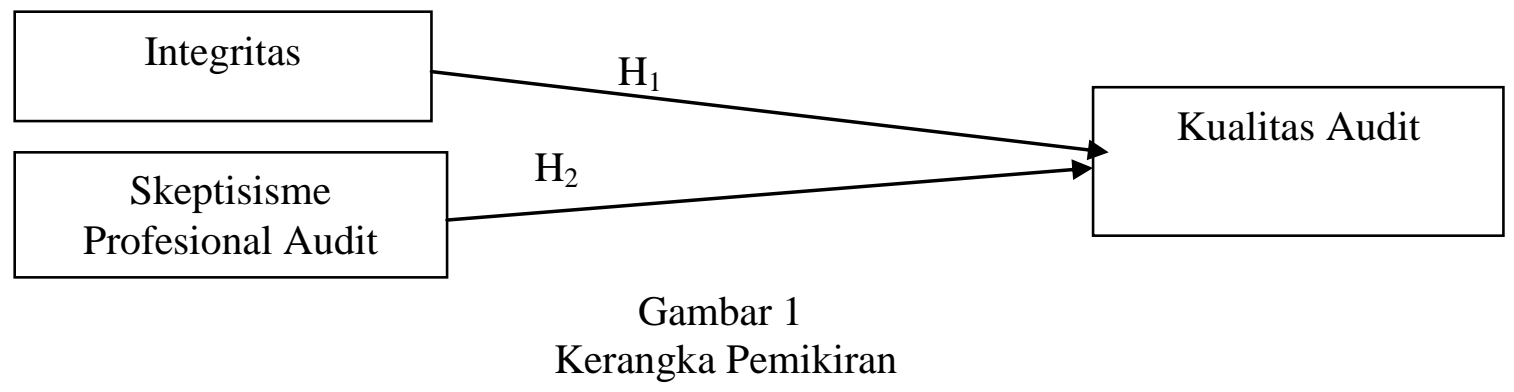

\section{HASIL PENELITIAN DAN PEMBAHASAN}




\section{A. Hasil Penelitian}

\section{Uji Validitas dan Reliabilitas}

Setelah melalui uji validitas untuk seluruh item pertanyaan kuisioner variabel Integritas menunjukan seluruhnya valid, karena nilai $\mathrm{r}$ hitung $>\mathrm{r}$ tabel. Artinya item pertanyaan layak di gunakan dalam penelitian ini.

Tabel 1

Validitas

\begin{tabular}{|l|l|l|l|}
\hline Variabel & $\begin{array}{l}\text { r } \\
\text { hitung }\end{array}$ & r tabel & Keterangan \\
\hline Integritas & 0,803 & 0,312 & Valid \\
\hline Skeptisisme Profesional Auditor & 0,654 & 0,312 & Valid \\
\hline Kualitas Audit & 0,747 & 0,312 & Valid \\
\hline
\end{tabular}

Begitupun halnya dengan uji reliabilitasnya instrumen variabel Integritas dinyatakan reliabel yang ditunjukan dengan nilai alpha croncbach nilainya lebih besar dari 0,70 .

Tabel 2

Realiabilitas

\begin{tabular}{|l|r|r|}
\hline \multicolumn{3}{|c|}{ Reliability Statistics } \\
\hline Varaibel & Cronbach's Alpha & N of Items \\
\hline Integritas & $\mathbf{. 9 3 8}$ & $\mathbf{1 5}$ \\
\hline Skpetssisme Profesional Audit & .887 & $\mathbf{1 6}$ \\
\hline Kualitas Audit & $\mathbf{. 9 2 1}$ & $\mathbf{1 7}$ \\
\hline
\end{tabular}

\section{Uji Asumsi Klasik}

a. Uji Normalitas

Berdasarkan uji normalitas yang dilakukan dengan menggunakan histogram PPlots, diketahui bahwa data penelitian bersifat normal.

b. Uji Multikolinieritas

Berdasarkan pengujian multikolinieritas, data dinyatakan tidak terindikasikan mengalami gangguan multikolinieritas. Dengan demikian, variabel-variabel independent dalam penelitian ini tidak saling berkorelasi, sehingga model regresi menjadi ampuh untuk memprediksi bagaimana pengaruh variabel independent terhadap dependent variabel.

c. Uji Heteroskedaktisitas

Berdasarkan pengujian heterskedaktisitas, data dinyatakan homoskedaktis atau terbebas dari gangguan heterskedaktisitas. Artinya, varians yang terjadi cenderung konstan sehingga model regresi dapat dijadikan sebagai prediktor 
yang tepat. Hal ini terlihat dari hasil Scatterplots yang cenderung berpencar dan tidak membentuk pola tertentu.

\section{d. Uji Autkorelasi}

Pengujian autokorelasi menunjukan bahwa data terbebas dari gangguan autokorelasi atau perbedaan yang mencolok antar pengamatan dalam satu periode ke periode yang lainnya. Artinya, tidak terjadi korelasi antara pengamatan satu dengan pengamatan yang lainnya. Hal ini ditunjukan oleh nilai Durbin Watson yang tidak mengalami autkorelasi negatif mapun positif.

\section{Persamaan Regresi}

\section{Tabel 3}

\section{Regresi}

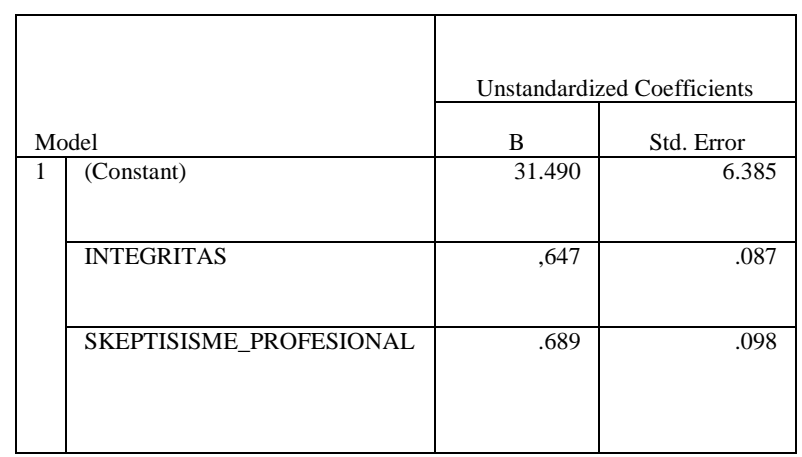

Persamaan regresi dari penelitian ini terlihat adalah $\mathrm{Y}=31,490+0,647 \mathrm{X}_{1}+0,647 \mathrm{X}_{2}+\mathrm{e}$. Nilai ini didapatkan dari tabel 3 hasil regresi dengan menggunakan SPSS. Terlihat nilai sebagai berikut. Apabila variabel $\mathrm{X}$ sama dengan 0, maka Y naik sebesar 31,490. Apabila integritas naik 1 satuan maka kulitas audit akan naik sebesar 0,647. Apabila skeptisisme naik sebesar 1 satuan maka kualitas audit akan naik sebesar 0,689.

\section{Korelasi}

Tabel 4

Korelasi

\begin{tabular}{|l|r|}
\hline Model & R \\
\hline 1 & \\
\hline
\end{tabular}

Berdasarkan tabel 4 menunjukan bahwa nilai korelasi sebesar 0,752. Artinya korelasi antara integritas dan skeptisisme profesional auditor dengan kualitas audit berarti kuat.

\section{Koefisien Determinasi}

Tabel 5

Koefisien Determinasi

\begin{tabular}{|l|c|}
\hline Model & $\begin{array}{c}\text { Adjuted R } \\
\text { Square }\end{array}$ \\
\hline 1 & \multicolumn{2}{|c|}{, 555} \\
\hline
\end{tabular}

Berdasarkan tabel 5 menunjukan bahwa nilai R sebesar 0,555 ini artinya bahwa terdapat hubungan integritas dan skeptisisme profesional audit terhadap kualitas audit sebesar 0,555 atau 55,5\%. Dan sebesar 0,448 atau 44,8 \% dipengaruhi faktor lain yang tidak di teliti. 


\section{Uji T-test}

Tabel 6

T-test

\begin{tabular}{|l|l|l|}
\hline & $\mathrm{t}$ & Sig. \\
\hline Constan & 4.932 & .000 \\
\hline Integritas Profesional & 2,567 & .014 \\
\hline $\begin{array}{l}\text { skeptisisme } \\
\text { Auditor }\end{array}$ & 2,286 &, 028 \\
\hline
\end{tabular}

Berdasarkan tabel 6 menunjukan bahwa nilai signifikasin integritas sebesar 0,014 ini berarti $\mathrm{H}_{1}$ diterima. Artinya terhadap pengaruh positif dan signifikan antara integritas dengan kualitas audit. Dan nilai signifikan skeptisisme profesional auditor sebesar 0,028 ini berarti $\mathrm{H}_{2}$ diterima yang berarti bahwa terhadap pengaruh positif dan signifikan antara skeptisisme profesional auditor terhadap kualitas audit.

\section{B. Pembahasan}

Integritas (X1) memberikan pengaruh positif dan signifikan terhadap kualitas audit. Terdapat hubungan yang kuat antara integritas Auditor terhadap kualitas audit(Y). Hal ini berarti apabila integritas Auditor meningkat maka kualitas audit juga pun akan meningkat. Dalam penelitian ini Integritas diproyeksikan menjadi tiga indikator yaitu kejujuran, keberanian dan tanggung jawab. Hal ini sejalan dengan teori yang diungkapkan oleh Abdul Halim (2008:29), bahwa faktor yang mempengaruhi kualitas audit adalah ketaatan Auditor terhadap kode etik yang terefleksikan oleh sikap independensi, objektivitas dan integritas. Integritas mengharuskan anggota untuk mentaati bentuk standar teknis dan etika (Sari, 2011). Hal tersebut menunjukkan bahwa dengan Integritas yang tinggi, maka Auditor dapat meningkatkan kualitas audit yang dihasilkannya. Hal ini Integritas Auditor pada Kantor Akuntan publik di daerah Jakarta Selatan berada dalam kategori baik.

Skeptisisme Profesional (X2) audit memberikan pengaruh yang positif dan signifikan terhadap kualitas Audit(Y). Terdapat hubungan yang kuat antara skeptisisme profesional Auditor dengan Kualitas Audit. Hal ini berarti apabila skeptisisme profesional audit meningkat maka kualitas auditnya pun akan meningkat. Dalam penelitian ini skeptisisme profesional diproyeksikan menjadi tiga indikator yaitu ketelitian, kewaspadaan profesional, kemahiran. Hal ini sejalan dengan teori yang diungkapkan oleh Theodorus (2011:94) yang menyatakan, sikap skeptisisme profesional Auditor akan mempengaruhi perilaku sikap skeptismenya dan pada akhirnya akan meningkatkan kualitas audit. Dalam penelitian ini indikator terapkan kehati-hatian memperoleh kategori cukup, hal ini menunjukan masih ada Auditor tidak berhati-hati dalam melakukan auditnya sehingga akan mempengaruhi kualias audit yang dihasilkan. Skeptisisme profesional Auditor pada Kantor Akuntan Publik didaerah Jakarta Selatan berada dalam kategori baik.

\section{KESIMPULAN DAN IMPLIKASI Kesimpulan}

Integritas (X1) memberikan pengaruh positif dan signifikan terhadap kualitas audit. Terdapat hubungan yang kuat antara integritas Auditor terhadap kualitas audit(Y). 


\section{National Conference of Creative Industry: \\ Sustainable Tourism Industry for Economic Development}

Universitas Bunda Mulia, Jakarta, 5-6 September 2018

ISSN No: 2622-7436

Hal ini berarti apabila integritas Auditor meningkat maka kualitas audit juga pun akan meningkat. Dalam penelitian ini Integritas diproyeksikan menjadi tiga indikator yaitu kejujuran, keberanian dan tanggung jawab.

Skeptisisme Profesional (X2) audit memberikan pengaruh yang positif dan signifikan terhadap kualitas Audit(Y). Terdapat hubungan yang kuat antara skeptisisme profesional Auditor dengan Kualitas Audit. Hal ini berarti apabila skeptisisme profesional audit meningkat maka kualitas auditnya pun akan meningkat. Dalam penelitian ini skeptisisme profesional diproyeksikan menjadi tiga indikator yaitu ketelitian, kewaspadaan profesional, kemahiran.

Integritas (X1) dan Skeptisisme Profesional (X2) memberikan pengaruh positif terhadap kualitas audit (Y). Dengan meningkatkan Integritas dan skeptisisme profesional seorang Auditor dapat meningkatkan kualitas kerja Audit. Sehingga laporan yang dihasilkan akan memberikan hasil yang semakin kuat dan handal. Dalam penelitian ini variabel Integritas berpengaruh lebih dominan dibandingkan Skeptisisme Profesional tingkat pengaruhnya dengan perbedaan tingkat signifikan yang tidak terlalu besar.

\section{Implikasi}

Untuk penelitian selanjutnya hendaknya dapat memperluas populasi penelitian, tidak hanya dilakukan diwilayah Jakarta Selatan saja. Sehingga hasil yang diperoleh dapat digeneralisasi untuk Auditor.Penelitian selanjutnya disarankan untuk mendapatkan data berupa wawancara dari beberapa responden penelitian agar bisa mendapatkan data yang lebih nyata dan bisa keluar dari pertanyaan-pertanyaan kuesioner yang mungkin terlalu sempit atau kurang menggambarkan keadaan sesungguhnya.

Menyadari bahwa integritas yang dimiliki Auditor akan mempengaruhi hasil kerja atau kinerja. Maka Auditor diharapkan memiliki intigritas yang tinggi sehingga dapat mendorong Auditor untuk melaksanakan pekerjaan dengan lebih baik lagi, terumata dalam hal Auditor mampu melakukan tindakan yang konsisten dengan nilai dan kenyakinan dirinya sebagai Auditor. Untuk menghasilkan hasil kerja yang berkualitas maka Auditor harus meningkatkan integritas yang mereka miliki, dengan senantiasa menyampaikan segala temuan, informasi dan data yang diperoleh dalam melakukan audit kepada pimpinan atau pihak yang diperiksa. Jadi dalam hal ini maka proses audit yang mereka lakukan menghasilkan kualitas laporan audit yang baik karena ditunjang dengan integritas yang mereka miliki. Skeptisisme Profesionalisme Auditor perlu ditingkatkan agar dalam melaksanakan tugasnya Auditor mempunyai cara untuk mencari tahu kebenaran suatu Laporan Keuangan. Seorang Auditor jangan terlalu percaya terhadap pihak manajemen tanpa bukti-bukti yang kuat dan temuan-temuan yang akurat. Sehingga dapat mengurangi hasil kesalahan.

Penelitian ini dapat dilanjutkan untuk mengetahui seberapa jauh variabel-variabel lain terhadap kualitas hasil kerja Auditor.

Diharapkan pada penelitian selanjutnya dalam mengadopsi kuesioner peneliti diharapkan mengembangkan daftar-daftar pernyataan pada penelitian ini. Serta memperhatikan faktor-faktor lain yang dapat mempengaruhi variabel dalam penelitian ini.

\section{DAFTAR PUSTAKA}

Agoes, Sukrisno, 2012. “Auditing Edisi 4 Buku 2”. Salemba Empat, Jakarta, 2012. Agoes, Sukrisno, 2004. “Auditing Edisi 3 Jilid 1”. Salemba Empat, Jakarta. 


\section{National Conference of Creative Industry: \\ Sustainable Tourism Industry for Economic Development}

Universitas Bunda Mulia, Jakarta, 5-6 September 2018

ISSN No: 2622-7436

Arens, Alvin A. Elder, Randal J dan Beasley, Marks S, 2008. "Auditing dan Jasa Assurance". Jilid 1. Edisi Kedua belas. Erlangga, Jakarta.

Ghozali, Imam, 2009. "Aplikasi Analisis Multivariate dengan Program IBM SPSS21", Badan Penerbit Universitas Diponegoro, Semarang.

Halim,Abdul, 2008. "Auditing (dasar-dasar Audit Laporan Keuangan)”. UU STIM, Jakarta.

Ikatan Akuntan Indonesia,2001. "Standar Profesional Akuntan Publik". Salemba Empat, Jakarta.

Mulyadi, 2002. “Auditing”. Jakarta : Salemba Empat, Jakarta.

Mulyadi, 2008. "Sistem Akuntansi”. Salemba Empat. Jakarta.

Mulyadi dan Kanaka Puradiredja, 1998. “Auditing” edisi 5 . Salemba Empat, Jakarta, 1998.

Rahmat, Jalaudin, 1998. “Metode Penelitian Komunikasi”. Bandung, Remadja Karya.

Simamora, Henr, 2002. “Auditing”. UPP AMP YKPN, Yogyakarta.

Singgih, Santoso, 2006. "Menguasai Statistik di Era Informasi dengan SPSS 14". PT. Elex Media Computindo, Jakarta.

Soekrisno, Agoes, 2004. "Auditing (Pemeriksaan Akuntan) oleh Akuntan Publik". Lembaga Penerbit Fakultas Ekonomi Universitas Indonesia. Jakarta.

Sugiyono, 2011. "Metode penelitian Kuantitatif Kualitatif dan $R \& D$ ". Alfabeta. Bandung.

Theodorus M Tuanakotta, 2011. "Berpikir Kritis dalam Auditing”. Salemba Empat, Jakarta.

Agustini, Endang Sri Rahayu, 2011. "Pengaruh Integritas dan Masa Perikatan Auditor terhadap Kualitas Audit Audit”. Universitas Komputer Indonesia, Bandung.

Arianti, Komang Priardi dkk, 2014 "Pengaruh Integritas, Objektifitas, dan Akuntabilitas terhadap Kualitas Audit Audit di Pemerintah Daerah". Universitas Pendidikan Ganesha, Buleleng.

Ariviana, Bella, 2014. "Pengaruh Akuntabilitas, Pengetahuan, Pengalaman dan Independensi Terhadap Kualitas Hasil Kerja Auditor”. Universitas Diponegoro, Semarang.

Effendy, Mutia dkk, 2014. "Pengaruh Skeptisme Profesional, Keahlian, Independensi dan Reduksi Kualitas Audit terhadap Kualitas Audit”. Universitas Lambung Mangkurat, Banjarmasin.

Indah, Herliandini Triraharyu, 2014. "Pengaruh Integritas dan Skeptisisme Profesional Auditor terhadap Kualitas Audit”. Universitas Komputer Indonesia, Bandung.

Indah, Siti Nur Mawar, 2010. "Pengaruh Kompetensi dan Indepensi Auditor terhadap Kualitas Audit”. Universitas Diponogero, Semarang.

Konarth F Larry, "Auditing A riskAnalisis Approach", $5^{\text {th }}$ edition.South western Thomson Learning, Canada.

Universitas Pamulang, 2015. "Panduan Skripsi Ekonomi”. Universitas Pamulang, Tangerang.

Utami, Nourma, 2011. "Pengaruh Independensi, Integritas dan Kewenangan terhadap

Efektivitas Peranan Komite Audit”. Universitas Islam Negeri Syarif Hidayatullah, Jakarta. 